\title{
On Dance Dramaturgy
}

\author{
Guy Cools ${ }^{1}$ \\ Fontys School of Fine and Performing Arts, Tilburg, Netherlands \\ E-mail: gjhcools@yahoo.ca
}

\section{Abstract}

In 1994, Marianne Van Kerkhoven, the Flemish godmother of dance dramaturgy wrote a short, seminal article on the subject - Looking without pencil in the hand - of which the title alone is already a manifesto. This contribution builds further on Van Kerkhoven insights': how the dramaturge has to stay necessarily invisible in the creative process (s)he is supporting; how in order to capture this invisible role, a lot of metaphors have been created.

It continues with looking at the different roles I take up in my own practice: that of somatic witness, dialogue partner and editor. It concludes reasserting the practice of the (dance) dramaturge as a creative practice in which the whole body is involved and in which somatic proximity to the creative process is as important as critical distance.

\section{Keywords}

Dance Dramaturgy. Somatic Witness.

Dialogue Partner. Editor.
Resumo

Em 1994, Marianne Van Kerkhoven, a madrinha flamenga da dramaturgia da dança, escreveu um pequeno artigo seminal sobre o assunto - Looking without pencil in the hand - do qual o título por si só já é um manifesto. Essa contribuição se desenvolve ainda mais nos insights de Van Kerkhoven: como o dramaturgo deve permanecer necessariamente invisível no processo criativo que ele(a) está apoiando; como, de modo a capturar esse papel invisível, muitas metáforas foram criadas. O texto continua com olhares para os diferentes papéis que assumo em minha própria prática: a de testemunha somática, parceiro de diálogo e editor. Ele conclui-se reafirmando a prática do dramaturgo (de dança) como uma prática criativa na qual todo o corpo está envolvido e na qual a proximidade somática do processo criativo é tão importante quanto a distância crítica.

\section{Palavras-chave}

Dramaturgia da dança. Testemunha somática. Parceiro de diálogo. Editor. 
Dance dramaturgy is a relatively young discipline and profession. The first official dance dramaturg in Europe was Raimund Hoghe, who got credited in that function with Pina Bausch in 1979. Soon after, other iconic, first generation figures followed such as Marianne Van Kerkhoven with Anne Teresa De Keersmaeker or Heidi Gilpin with William Forsythe.

One influential definition of dramaturgy, defines dramaturgy as the organisation of the actions of the performance, the 'weaving together' of the different, often multi-disciplinary threads of the work. It is understood that dramaturgical thinking and strategies contribute to the quality of the work, its readability and accessibility.

Since there is most of the time no text or script to start from, dance dramaturgy, which is often defined as 'open dramaturgy' is much more process oriented and is based on dialogical skills and the capacity to stimulate group dynamics and exchange. Marianne Van Kerkhoven, who is worldwide considered as one of the godmothers of the profession defined it as follows:

The type of dramaturgy I relate to, and which I try to apply both in theatre and dance, follows a certain 'process': we consciously choose material from various origins (texts, movements, film images, objects, ideas ...); the 'human

\footnotetext{
$1 \mathrm{Dr}$. Guy Cools is a dance dramaturge. Recent positions include Associate Research Professor at the research institute Arts in Society of the Fontys School of Fine and Performing Arts in Tilburg, and Postdoctoral Researcher at Ghent University, where he finished a practice-based $\mathrm{PhD}$ on the relationship between dance and writing. He has worked as a dance critic and dance curator. He now dedicates himself to production dramaturgy, contributing to work by choreographers all over Europe and Canada. His most recent publications include The Ethics of Art: ecological turns in the performing arts, co-edited with Pascal Gielen (Valiz, 2014); In-between Dance Cultures: on the migratory artistic identity of Sidi Larbi Cherkaoui and Akram Khan (Valiz, 2015) and Imaginative Bodies, dialogues in performance practices (Valiz, 2016). With the Canadian choreographer, Lin Snelling, he developed an improvised performance practice 'Rewriting Distance' (see also: www.rewritingdistance.com) that focuses on the integration of movement, voice, and writing. Cools lives in Vienna.
}

material' (actors/dancers) clearly prevails over the rest; the performers' personalities and not their technical capacities is the creation's foundation. The director or choreographer starts off with those materials: in the course of the rehearsal process he/she observes how the materials behave and develop; only at the end of this entire process do we gradually distinguish a concept, a structure, a more or less clearly outlined form; this structure is by no means known at the start. (KERKHOVEN, 1997, pp. 20-21).

At a higher level of organization, the dramaturgical reflection is also a meta reflection on the development of the artist's career, the creative process and its methodologies, the interdisciplinary collaboration processes, the role and the function of the artists/organizations within society and the relationship the artist wants to establish with society.

In another of her seminal essays, of micro and macro dramaturgy (1999), Marianne Van Kerkhoven defined micro dramaturgy as 'the dramaturgy that situates itself around a concrete production'; while the macro dramaturgy deals with 'the social relevance and function of the theatre'. For Van Kerkhoven, the dramaturg always tries to build bridges between the micro and the macro dramaturgy and as such supports the artists in their attempt 'to help us read the world and to decipher its complexities'.

\section{The dramaturg needs to remain invisible}

An earlier short essay, Looking without a pencil in the hand (1994), which Marianne Van Kerkhoven published in the On Dramaturgy themed issue of Theaterschrift (of which she was the series editor), remains to this day the main reference point for many more recent publications. It is so as much for its unpretentious, honest content as for its poetic form. In 12 short axiomatic state- 
ments, framed between two quotes by Susan Sontag and Paul Valéry (the latter from which it derives its title), she captures all the essential attitudes and qualities - both artistically and ethically - that a dramaturg should work and live by. For instance:

9. Dramaturgy is a limited profession. The dramaturge must be able to handle solitude; he/she has no fixed abode, he/she does not belong anywhere. The work he does dissolves into the production, becomes invisible. He/she always shares the frustrations and yet does not have to appear on the photo. The dramaturge is not (perhaps: not quite or not yet) an artist. Anyone that cannot, or can no longer, handle this serving - and yet creative - aspect, is better out of it. (Marianne Van KERKHOVEN, 1994, p. 144).

Her statement about the necessary invisibility of the dramaturg was picked up and developed by Cindy Brizelli and André Lepecki in their introduction to the 2003 special dramaturgy issue of the feminist journal Women and Performance, which they entitled The labor of the question is the (feminist) question of dramaturgy: "Invisible labor then, tainted with mythical resonances. For the dramaturg sides not only with women's manual labour, it sides also with a certain fantasy of the maternal - the dramaturg solves problems, smoothes out the psychosis of the production and upon request, must always be able to provide the right answer." (LEPECKI, 2003, p. 15). Even in a much more recent themed issue of a journal, on Dance and Movement Dramaturgy (2013) by the Canadian Theatre Review, writers continue to reference Van Kerkhoven's essay and discuss the dramaturg's 'chameleonlike figure' (MONTAIGNAC, 2003, p. 10), or, as Jacob Zimmer summarizes it in his more ironical style: "Dramaturgy's constant definition is the running joke of conferences and also the strength of the field. The constant reflec- tion and deeply personal formulations is the feature, not the fault." (ZIMMER, 2003, p. 17).

The inevitable invisibility of the dramaturg's contribution to the final work has often led to a mystification of his or her role in the creative process. It has resulted in a wealth of images and attempts of finding a metaphorical language to try and capture and define the nature of the role. Metaphors that have been used for the dramaturg include the very established but problematic 'outside eye', or the more poetic 'magpie, collecting everything that shone' (RADOSAVLJECIC, 2009, p. 46), a 'huge backpack of useful and non-useful bits of information' (KERKHOVEN), a 'compass bearer' (TURNER; BEHRNDT; RADOSAVLJECIC 2009, p. 50). Among the metaphors that I prefer myself are:

\section{Midwife}

A dramaturg is like a midwife. You support the process that will happen anyway, even without your presence. You use your experience from previous, similar processes to guide the 'parents/artists' and ninety percent of the time you just reassure them that everything is happening as it should be. And even during the ten percent of time when you do interfere, you learn to be patient and to hold back because you know that the more natural the birth, the more joy there will be. The metaphor of the midwife also resonates with the notion of the Socratic midwife who supports the emergence of new ideas.

\section{Kitchen help}

As a student, I worked a lot in restaurant kitchens and I have often since compared the art of choreography to the art of cooking - to use the same metaphor that George Balanchine did. It is a matter of choosing the right ingredients/people and then it is a matter 
of finding the right order and rhythm so that the individual tastes/talents reinforce rather than weaken each other. As a dramaturg I feel privileged to have worked in the kitchens of great chefs and my main contribution has often been to pass on recipes from one to another. I share this metaphor with Marianne Van Kerkhoven who in the opening paragraph of Looking without a pencil in the hand states that the "request to talk or write about her work leads to a feeling of awkwardness, similar to the feeling of being asked to reveal someone else's culinary secrets or recipes" (KERKHOVEN, 1994, p. 140).

\section{Outside body}

I am more than just my eyes. Following an argument originally introduced by André Lepecki, Myriam Van Imschoot (2003) states that the notion of the 'outside eye' separates the dramaturgy from the artist's body.

\begin{abstract}
"What Lepecki resists is the idea of the dramaturg (the eye) as the locus of power and knowledge, put at disposal of a choreographer, who (if we extend the metaphor) is perceived as being all body - a blind and dumb body, waiting to be illuminated by sight and speech."(IMSCHOOT, 2003, p. 63).
\end{abstract}

I therefore prefer the term 'outside body'. I used it for the first time for the program brochure of R.A.F.T. (2005), an improvisation project realized by Marc Boivin in Montréal for which I was asked to be the dramaturg. I was present at all the rehearsals and the first series of public performances and felt that my outside, silent body was an integral part of the show. Christel Stalpaert has further deepened this notion of the 'outside body' in her vision of a corporeal dramaturgy (STALPAERT, 2009, 2014).

Essentially, the issue of defining the work of the dramaturg goes back to the tra- ditional dichotomy of process and product. Is dramaturgy a quality of the final result, of the performance, or is it an attitude that accompanies the creative process, the becoming of the work? Traditional definitions of dramaturgy favour the first, like for instance Eugenio's Barba's classic definition:

The word text, before referring to a written or spoken, printed or manuscripted text, meant 'a weaving together'. In this sense, there is no performance which does not have 'text'. That which concerns the text (the weave) of the performance can be defined as 'dramaturgy', that is, drama-ergon, the 'work of the actions' in the performance. (BARBA, 1991, p. 68).

The more process-oriented nature of dance dramaturgy also leads to it often being described as movement itself. Already in an early essay on dance dramaturgy, Jean Marc Adolphe defined dance dramaturgy as 'an exercise in circulation' (ADOLPHE, 1997 , p. 33). Dramaturgy as movement is also the recurrent theme in the special issue of Performance Research, On Dramaturgy (2009), which itself was a follow up to the international conference European Dramaturgy in the 21st Century, held in Frankfurt am Main in 2007. In her self-reflection on her work as a dramaturg in the UK, The Need to keep Moving, Duska Radosavljevic defines herself with references to De Certeau's The Practice of Everyday Life as 'a (moving) body in the theatre making environment' (RADOSAVLJECIC, 2009, p. 45) whose 'gypsy-condition' (Id, p. 50) and 'being on the margin, both literally and metaphorically' allows for 'bridge-building' and "a negotiation between frontiers between theory and practice, between writers and directors, between the show and the audience, between theatre and academia and sometimes between different cultures, too." (Id, p. 48). For many, this necessary movement 
of the dramaturg is a movement between proximity and distance. Maaike Bleeker invokes Deleuze and Guatttari's discussion of friendship in What is philosophy? (1994) when she describes the relationship between dramaturg and choreographer as the momentum that initiates 'thoughts that move'. This relationship between dramaturg and choreographer is itself "a movement that involves both closeness and distance, both similarity and difference" (BLEEKER, 2003, p. 163). The same reference to Deleuze's notion of friendship is picked up by Bettina Masuch (2009, p. 137), discussing her relationship with Meg Stuart. Also Bojana Cvejic invokes the figure of "the friend so as to do away with instrumentality and specialization of the role and relationship of dramaturg with choreographer" (CVEJIC, 2009, p. 25). And Jacob Zimmer (2009) entitles his contribution to the themed issue of the Canadian Theatre Review Friendship is no day job and other thoughts of a resident dance dramaturg (ZIMMER, 2013, p. 16).

Bojana Kunst finally places the 'flexibility' of the dramaturg to move between positions and her 'affective proximity' to the creative process within the current socio-economical Post-Fordian discourse of changes of production and labour:

A major reason for the entry of dramaturgy into dance can be found in the changing contexts of artistic practice and social labour. The entry of the dramaturg into dance could be read as a consequence of the changes in the political economy of labour, where the production of language, contexts and human cognitive and affective abilities is pushed to the foreground. (...) This is why the dramaturg's work is strongly characterized by flexibility: as a participant in the process, the dramaturg can occupy a variety of roles - those of practical dramaturg, producer, festival director, stage manager, writer, journalist, teacher, workshop leader, coach, lecturer, academic, artist, dancer, production network member, cultural politics advisor, mentor, friend, compass, memory, fellow traveler, mediator, psychologist. (KUNST, 2009, pp.85-86).

I myself have occupied all the above-mentioned roles, but in my own ongoing process of trying to situate myself, I define dramaturgy today as the critical reflection of the artist as to the why and how to develop one's language and one's creative process. My interest and focus have shifted from supporting the creation of a particular production to the development of a particular artistic language, and from there to the creative process as such. If I am able to offer artists tools to transform and improve their creative process, eventually also the language and the work resulting from it will evolve.

\section{The dramaturg as witness, dialogue partner and editor}

Although the text corpus on dance dramaturgy has recently begun to grow substantially, there is still very little literature that describes the actual work a dramaturg does within the creative process. Katalin Trencsényi's Dramaturgy in the Making (2015) is one of the few exceptions. André Lepecki, discussing his collaboration with Meg Stuart, lists a series of tasks ranging from 'reading all the books suggested by the choreographer' to 'remembering something that had happened months before, had been discarded and now was necessary again.' (LEPECKI, 2009, pp. 66-67).

The overview Liesbeth Wildschut gives in Reinforcement for the choreographer. The dance dramaturge as ally, the chapter on dance dramaturgy in Contemporary Choreography. A critical Reader (2009), itemizes a long list of questions the dramaturg is supposed to ask at different stages of the process. But the series of verbs that accompany these questions - to reflect, to comment, to 
analyse, to interpret, ... indicate that she continues to situate the dramaturg's contribution mainly within the rational, analytical domain of adding 'meaning' and 'coherence'.

The one who comes closest to the way I describe my own practice as a dramaturg is Katia Montaignac who distinguishes three different functions: that of witness, discussion partner and of scholar carrying out research (MONTAIGNAC, 2013, p. 11). Although the latter is also a possible task, I do not consider it a specific part of the creative process, or unique to the dramaturg. The three roles I would describe essential to the work of the dramaturg are those of: the (silent) witness, the dialogue partner or moderator, and the editor.

\section{The dance dramaturg as somatic witness}

(...) the artist Chris Burden described those watching him that night not as an audience or as spectators but as witnesses. It's a distinction I come back to again and again and one which contemporary performance dwells on endlessly because to witness an event is to be present at it in some fundamentally ethical way, to feel the weight of things and one's own place in them, even if that place is simply, for the moment, as an onlooker. (ETCHELLS 1999, p. 17).

In a similar way to Tim Etchells in the quote above, Ann Cooper Albright describes (in the introduction to her book, Choreographing Difference. The Body and Identity in Contemporary Dance (1997) how watching the performance La Tristeza Complice by Les Ballets $C$ de la B/Alain Platel transformed her 'act of watching into the act of witnessing'.

To witness something implies a responsiveness, the response/ability of the viewer towards the performer. It is radically different from what we might call the 'consuming' gaze that says 'here, you entertain me, I bought a ticket, and
I 'm going to sit back and watch'. (...) In contrast, what I call witnessing is much more interactive, a kind of perceiving (with one's whole body) that is committed to a process of mutual dialogue. (ALBRIGHT, 1997, p. xxii).

Bringing the witness role into the studio, as early as possible in the creation process, is one of the most powerful things you can contribute as a dramaturg. Already through your silent, but felt, presence, you will influence somatically and energetically the dialogue between choreographer and performers and among the performers themselves.

Very little literature on dance dramaturgy talks about this somatic and energetic potential of the witness role. Christel Stalpaert mentions the dramaturg Carmen Menhert describing her work as a 'dialogue on an energy level' (STALPAERT, 2009, p. 123) and Eleonara Fabiao discusses it more explicitly in her contribution to the issue On Dramaturgy of Women and Performance:

I could explore a quality of interaction that interests me a lot, a kind of 'energetic communication'. It may seem abstract, but this way of acting upon someone is as concrete as it is effective. As some understandings can only be formulated through a good conversation, others can only be produced by this kind of interchange, through the intersection of energy and silent talk. You can energize and be energized (or stimulate and be stimulated) if you concentrate your attention. Actors and directors are particularly trained to work things out in this way. And, as I understood, dramaturgs can also take great advantage attending to this communicational strategy. If one of the most interesting specificities of the theatrical scene is the magnetic quality of presences, the importance of investigating and generating energetic ways of communication seems obvious. (FABIAO, 2003, p.30).

For me the witness role is an essential, creative part of my work as a dramaturg. 
The intuitive play with proximity or distance towards the process is mainly there to create subtle shifts in the witness role that might influence the interaction on the floor between performers and/or choreographer. In the early stages of a rehearsal process I also like to physically participate and experience the physical research on my own body. It is also a way to make the distance to both the material and the people as intimate as people. When at the later stages I constantly exit and re-enter the process, my felt presence or absence also energetically shifts the shared space and our 'relationality' and by doing so subtely influences the process.

\section{Dance dramaturgy as a dialogical practice}

Early, before rehearsals, the most important work happens: conversations that clarify the questions and curiosities that lead to making a piece. We talk about how to work, how to create vocabulary, structure, and meaning. We talk about where to work since different rehearsal spaces produce different shows. We talk about when to work since different schedules produce different shows. We talk about what to do in the rehearsal - what kind of training, how much talking, how much doing: should there be field trips, improvisation? (ZIMMER, 2013, p. 17).

Maaike Bleeker sees in the dialogue the moment where the dramaturgical reflection of which the choreographer is also capable himself, becomes exteriorized in another person, the dramaturg (BLEEKER, 2003, p. 166). Dramaturg André Lepecki in his collaboraton with Meg Stuart defines this dialogical practice as an 'act of translation' from "Meg to the dancers; from the dancers to the dancers; from Meg to Meg; from the dancers to Meg; from myself to Meg; from myself to the dancers; and form all of these to all the other collaborators." (LEPECKI, 2010 , p. 66). In his enumeration of dramaturgical activities it is just one of many. For Meg Stuart herself, however, it is the essence of their collaboration: "A dramaturgical process begins with a dialogue with someone you trust. (...) They are also a big ear with whom I share my initial questions and later my doubts, so as not to spill them all over the studio." (STUART, 2010, p.134).

Similarly to how Jacob Zimmer describes the importance of conversation before the start of the rehearsal process, my work as a dramaturg happens as much outside of the studio as inside. Whereas inside the studio the witness role is the more dominant one, outside of it I meet with the choreographer on a regular basis (anywhere from daily to weekly depending on the needs of the process) to discuss what is happening in the studio. These conversations ideally start as early as possible, when the first ideas for a new creation germinate (sometimes while still working on the previous piece) and they intensify during the course of the rehearsal process. Similarly to how I described earlier that my focus shifted from the final result to the creative process, these discussions don't so much focus on the material that is developed but on what is needed to further nurture the process: for instance in the communication with the performers; what kind of input they need; how best to plan and organize the time of the rehearsals; how to start thinking about a possible way to organize the material parallel to its development.

The time and the place of these conversations is crucial and changes with each choreographer and/or production. And also their form requires some reflection. A number of times it happened for instance by writing letters and these days it is often done on a distance through Skype or FaceTime. 
As such, conversation is very different from so-called feedback. It is much more open-ended and purposeless. The only kinds of feedback that seem relevant and useful in this particular conversation are reminders of previous ideas and conversations, which serve to reconnect with the journey one set out on together. I am big believer in the notion that in the creative process 'the first ideas are always the right ones'. As such the feedback is often only there to remind the choreographer of these-initial, most vital lifelines of the work.

\section{The dance dramaturg as editor}

"One of the editor's obligations is to carry, like a sacred vessel, the focus of attention of the audience and move it in interesting ways around the surface of the screen." (MURCH; in ONDAATJE 2002, p. 277)

When I first read the book "The Conversations, Walter Murch and the Art of Editing Film by Michael Ondaatje" (2002), I immediately recognized myself as a production dramaturg in the role of the film editor. In the form of open dramaturgy I practice, the editing process happens on the floor where, through accidents and changes in the process, the material reveals by itself how it is best connected. Often it is merely a matter of being attentive, recognizing the moments and acting upon them.

A main function of the editing process is to keep the audience engaged. In the field of neuroscience, studies have shown that engagement is always the result of a combination of recognition and surprise. Too much recognition leads to boredom. Too much surprise doesn't allow spectators to connect, to enter your world. So you need a unique balance of both elements, which will also differ depending on the overall context in which you situate your work. Classical arts will generally elicit more re- cognition. Contemporary arts might work more explicitly with the element of surprise.

In the editing process you are mainly editing the rhythm of the piece. For John Dewey rhythm is the essential formal principle both in science and in art. "Because rhythm is a universal scheme of existence, underlying all realization of order in change, it pervades the arts, literary, musical, plastic and architectural, as well as the dance." (DEWEY 1934, p. 156). Dewey defines rhythm as the 'ordered variation of changes' (Id, p. 160). The rhythm of art to a certain extent always copies both the rhythm of the human body (its breathing, the pulse of its blood circulation, ...) and the rhythms of nature; that is again the 'oscillation between inside and outside'.

Dewey continues to stress the importance of the 'universality of intervals in works of art'. "They specify and they relate at the same time." (Id, p. 164). When, as a dramaturg, I support the editing process of a dance piece, a lot of my attention is focussed on the transitions between sections. In order to achieve an engaging variety in the rhythm of the piece, every transition requires a unique solution. It is in the non-beat, the pauses, where the unique quality of a rhythm is defined. "In rhythmic ordering, every close and pause, like the rest in music, connects as well as delimits and individualizes." (Id, p. 179).

In the performing arts, the two main senses being adressed are the eye and the ear. The visual rhythm and the auditory rhythm are separate tracks that are still connected and influence each other. "The eye is the sense of distance. (...) Sounds come from outside the body, but sound itself is near, intimate. (...) Generically speaking, what is seen stirs emotion indirectly, through interpretation and allied idea. Sound agitates directly, as a commotion of the organism itself." (Id, pp. 246247) That is one of the reasons why auditory rhythm is always stronger than visual rhythm 
and why the relationship between music and movement is such a crucial one. The music can support but can also kill the visual impact.

Finally, as Murch indicates in the quote above, you also have to guide the audience's focus of attention. On stage every body is a centre of attention. But whereas in traditional Western theatre practices the centre of attention has always been explicit, in contemporary practices there are often multiple centres of attention. Cunningham refused to have a clear centre of focus and Anne Teresa De Keersmaeker explored for a long period in her career the ellipsis form, which always has at least two equal centres. In the editing process, there are ways to clarify and frame the different centers of attention so that the audience will follow them with you or will realize that they have the freedom to decide for themselves.

\section{Conclusion: dramaturgy as a crea- tive and somatic practice}

Even in its relatively short professional history, (dance) dramaturgy has been mainly associated with the theoretical, rational component of knowledge: the 'outside eye' which from a distance keeps an overview and gives meaning and coherence to the embodied practice of the makers and doers, the artists.

Contemporary dramaturgical practices, however, blur this dichotomy. The creative 'friendship' between dramaturg and choreographer presumes as much promixity and intimacy as distance. Already in the witness function, the 'outside eye' becomes an 'outside-body' which creatively plays with varying its distance to the creative process and by doing so influences the process somatically and energetically. Even in the more conventional functions of the dialogue partner who listens, and the editor who helps to shape the rhythm, the who- le physicality of the dramaturg is involved.

\section{Bibliography}

ADOLPHE, Jean-Marc (1997), La dramaturgie est une exercise de circulation pour tenir le monde a l'ecart, in: Nouvelles de Danse, Dossier Danse et Dramaturgie, nr. 31 (1997). Brussels: Contredanse. pp. 31-34.

ALBRIGHT, Ann Cooper (1997), Choreographing Difference: The Body and Identity in Contemporary Dance. Middletown: Wesleyan University Press.

BARBA, Eugenio (1991), Dramaturgy, in: Barba, Eugenio and Savarese, Nicola (eds.): A Dictionary of Theatre Anthropology: The secret art of the performer. London, New York: Routledge, pp. 68-73.

BEHRNDT, Synne K. and Turner, Cathy (2008), Dramaturgy and Performance, Palgrave Macmillan.

BLEEKER, Maaike (2003), Dramaturgy as a mode of looking, in: Brizell, Cindy and Lepecki, André (eds.), On Dramaturgy, the labor of the Question. Women \& Performance: a journal of femininst theory. Vol. 13:2, Issue 26. New York: NYU. pp. 163-172.

CVEJIC, Bojana (2009), The Ignorant Dramaturg, in: Blok Suzy (ed.), Perspectives on Potential Dance Dramaturgies. Amsterdam: Dancemakers. pp. 22-33.

DEWEY, John (1934/2005), Art as EXperience. New York: Penguin Books, Perigee Paperback edition. 
ETCHELLS, Tim (1999), Certain Fragments, Contemporary Performance and Forced Entertainment. London: Routledge.

FABIAO, Eleonora (2003), Dramaturging with Mabou Mines: Six proposals for Ecco Porco, in: Brizzell, Cindy and Lepecki, André (eds.), On Dramaturgy, the labor of the Question. Women \& Performance: a journal of femininst theory. Vol. 13:2, Issue 26. New York: NYU. pp. 29-40.

GRITZNER, KAROLINE, PRIMAVESI, PATRICK and ROMS, HEIKE (eds.) (2009), On Dramaturgy. Performance Research. Vol 14. No. 3., London: Routledge.

KUNST, Bojana (2009), The Economy of Proximity. Dramaturgical work in contemporary dance, in: Gritzner, Karoline, Primavesi, Patrick and Roms, Heike (eds.), On Dramaturgy. Performance Research. Vol 14. No. 3. London: Routledge. pp. 81-88.

LEPECKI, André (2010), Dramaturging, A quasi-objective gaze on anti-memory, in: Peeters, Jeroen (ed.), Are we here yet? Dijon: Les presses du réel. pp. 64-71.

LEPECKI, André and BRIZZELL, CINDY (2003), Introduction: The Labor of the Question is the (feminist) question of dramaturgy, in: Brizzell, Cindy and Lepecki, André (eds.), On Dramaturgy, the labor of the Question. Women \& Performance: a journal of femininst theory. Vol. 13:2, Issue 26. New York: NYU, pp. 15-16.

MASUCH, Bettina (2009), (no title), in: Peeters, Jeroen (ed.), Are we here yet? Dijon: Les presses du réel. pp. 136-137.
MONTAIGNAC, Katya (2013), Paradoxes of the Dance Dramaturg, in: Hansen, Phil (ed.), Dance and Movement Dramaturgy, Canadian Theatre Review, 155. Toronto: University of Toronto Press, pp. 10-15.

ONDAATJE, Michael (2002): The Conversations, Walter Murch and the Art of Editing Film. Toronto:

PEETERS, Jeroen (ed.) (2010), Are we here yet? Dijon: Les presses du réel.

RADOSAVLJEVIC, Duska (2009), The Need to Keep Moving, Remarks on the place of a dramaturg in twenty-first century England, in: Gritzner, Karoline, Primavesi, Patrick and Roms, Heike (eds.), Performance Research, On Dramaturgy, Vol 14, No. 3. London: Routledge, pp. 45-51.

STALPAERT, Christel (2009), A Dramaturgy of the Body, in: Gritzner, Karoline \& Primavesi, Patrick \& Roms, Heike (eds.), Performance Research. On Dramaturgy, Vol 14, nr. 3. Abingdon: Routledge. pp. 121-125.

STALPAERT, Christel (2014), Becoming the Outside Body, Implicated in the Life of Others: Corporeal Dramaturgy and the Ethics of Instability / Sustainability, in: Pewny, Callens, Coppens (eds.), Dramaturgies in the New Millennium. Relationality, Performativity, and Potentiality. Theater Schriftenreihe. Gunter Narr Verlag.

STUART, Meg (2010), The Big Ear, in: Peeters, Jeroen (ed.), Are we here yet? Dijon: Les presses du réel. pp. 134-135.

TRENCSENYI, Katalin (2015), Dramaturgy in the Making. London: Bloomsbury. 
KERKHOVEN, Marianne Van (1997), Le processus dramaturgique, in: Nouvelles de Danse, Dossier Danse et Dramaturgie, nr. 31. Brussels: Contredanse. pp. 18-25.

KERKHOVEN, Marianne Van (1994), Writing without a pencil in the hand, in: Van Kerkhoven, Marianne (ed.), Theaterschrift 5-6, On Dramaturgy. Brussels: Kaaitheater. pp. 140-148.

IMSCHOOT, Myriam Van (2003), Anxious Dramaturgy, in: Brizzell, Cindy and Lepecki, André (eds.), On Dramaturgy, the labor of the Question. Women \& Performance: a journal of femininst theory. Vol. 13:2, Issue 26. New York: NYU. pp. 57-68.

WILDSCHUTH, Liesbeth (2009), Reinforcement for the choreographer: The dance dramaturg as ally, in: Butterworth, Jo \& Wildschut, Liesbeth (eds.), Contemporary Choreography. A critical reader. Oxon: Routledge. pp. 383-398.

ZAPPEN, James P. (2004), The Rebirth of Dialogue. Bakhtin, Socrates, and the Rhetorical Tradition, New York: State University of New York Press.

ZIMMER, Jacob (2013), Friendship is no day job and other thoughts of a resident dance dramaturg, in: Hansen, Phil (ed.), Dance and Movement Dramaturgy, Canadian Theatre Review, 155. Toronto: University of Toronto Press. pp. 16-20.

Recebido: 28/08/2019

Aprovado: 29/11/2019 